\title{
VAT Liabilities of Electronic Service Providers in Turkey
}

\author{
Erdem Ateşağaoğlu ${ }^{1}$ \\ M. Süheyl Karakaya²
}

RESEARCH

ARTICLE

\begin{tabular}{l} 
ARTICLE INFO \\
\hline Submitted : 01.03.2019 \\
Revised : 11.04.2019 \\
Accepted : 16.04.2019 \\
Available : 30.07.2019 \\
\hline iThenticate similarity \\
score: 6\% \\
\hline JEL classification: \\
K34, K24 \\
\hline Keywords: \\
Value added tax, E- \\
commerce, Business to \\
consumer (B2C), \\
Electronic service \\
provider, Foreign \\
vendor
\end{tabular}

\section{TICLE INFO}

Revised : 11.04.2019

Accepted : 16.04.2019

iThenticate similarity score: $6 \%$

JEL classification:

K34, K24

\section{Keywords}

Value added tax, Ecommerce, Business to vendor

\begin{abstract}
A B S T R A C T
Topic of our paper is the new system in VAT taxation of B2C e-commerce transactions between commercial corporations and customers executed via internet- in Turkey and the problems arising from such imposition of VAT on B2C e-commerce. This topic will be assessed in three parts. In the first part, general frame of VAT in Turkey will be briefly explained in order to understand the applicable new system in taxation of $\mathrm{B} 2 \mathrm{C}$ e-commerce. In second part, the new system in taxation of B2C e-commerce regulated via Communique No. 17 on VAT and its problems will be elaborated and also evaluated. Particularly; the concept of electronic service provider, registration obligation of this person as taxpayer, threshold for relevant registration, the general and punitive measures against noncompliance of new system, the possible problems and failures will be arisen as to the application are the main points regarding this issue. In final part, possible drawbacks in the area of execution and the role of the banks in the new system and generally positive outcomes will be considered and shared about the new VAT system of B2C e-commerce. If it needs to make some general inferences, we think that what will happen in the future should be evaluated due to specific uncertainties arising from implementation of new system, although it seems to be working.
\end{abstract}

Cite this article as: Ateşağaoğlu, E. \& Karakaya, M.S. (2019). "VAT Liabilities of Electronic Service Providers in Turkey", International Journal of Public Finance, 4(1), 23-38.

\footnotetext{
1 Assoc. Prof. Dr., ORCID: 0000-0003-0018-3508, İstanbul University, Faculty of Law, Fiscal Law Department, Turkey, eatesaga@istanbul.edu.tr

2 ORCID: 0000-0002-5255-6516, İstanbul University, Faculty of Law, Turkey, karakayasuheyl@gmail.com
} 


\section{General Framework of VAT in Turkey}

\subsection{Taxable Event}

Value added tax (hereinafter "VAT") in Turkey is regulated under the Value Added Tax Law, Law No.3065 ("hereinafter VAT Law"). Article 1 of the VAT Law provides that, among other things, deliveries and services which are deemed as commercial, agriculture, industrial or self-employment activities and the importation of goods and services will trigger the payment of VAT (Mutluer, 2007: 281). Therefore, VAT is payable on every transaction involving production or the performance of a service and the taxable event is directly connected with delivery or importation of a good or execution or importation of a service (Kaneti, 1989: 388). Also, the article 10/1-b of the VAT Law set out that issuance and delivery of an invoice or similar documents before delivery of goods or rendering of services is evaluated as taxable event. Besides, it is stated in the article 10/1-I that the commencement date of custom tax liability is also considered as taxable event for VAT purposes regarding the import transactions (Mutluer, 2007: 286; Şişman, 2014: 250).

The meaning of delivery is clarified under the article 2/1 of the VAT Law. In this regard, delivery concept is the transfer of the right of disposition on a property to the buyer or those acting on the buyer's behalf by the owner or those acting on the owner's behalf (Mutluer, 2007: 282; Şenyüz, Yüce \& Gerçek, 2018: 256; Oktar, 2018, 193). Moreover, according to article $2 / 1$ of the VAT Law, it is also regarded as delivery when initiation of the shipment started or when the delivery of goods to the carrier or driver took place. Taxable events have been required to occur in Turkey. In this context, pursuant to the article 6 of VAT Law, the delivery transaction or service should be fulfilled or benefiting from the service in Turkey (article 6 of the VAT Law).

On the other hand, there are certain VAT exemptions or tax refund available regarding exportation of goods and services (article 11), transit transportation and business concerning the transportations of cargo and passenger between Turkey and foreign countries by shipping, airway, road and railway (article 14), transactions carried out by banks and insurance companies and subject to banking and insurance transaction tax (article 17/4-e), deliveries of goods from Turkey to the free zone areas (article 12/1) and the services performed in free zone (article 17/4-1), sale of the participation shares and real estates by corporations on condition that the real estate is held at least for 2 years (article 17/4-r) and etc., set out in the articles 11-17 of the VAT Law (See Oktar, 2018: 193-209). There is also VAT refund for the non-resident passengers (article 11/1-b) and tax exemption for goods have no commercial value exceeding $150 €$ regulated via article 167/1-4 of the Customs Law No, 4458 (Şenyüz, Yüce \& Gerçek, 2018: 303).

Another significant VAT exemption is connected with export-registered deliveries (article 11/1-c). According to the provision, VAT of goods delivered by a manufacturer taxpayer resident in Turkey to such exporters, under the condition of exportation, shall not be paid by exporters. In such condition, VAT shall be declared in the statement for the period concerned and shall be assessed, accrued and deferred 
by the tax office, even if that VAT amount shall not be collected by exporters (Mutluer, 2007: 288). However, in case the goods concerned are exported within 3 months following the delivery date to an exporter, the VAT amount which was deferred, shall be canceled. Within this respect, when purchasing the goods from the suppliers in Turkey, the exporter located in Turkey will purchase these "subject to exportation" so that no VAT is paid. VAT subjected to such exemption will be arisen in the event that the exportation of goods is not be completed within three months of the purchase date.

There is also a VAT refund mechanism only for delivery of goods and services that are either exempted from VAT or are subject to the reduced rate of VAT (Article $29 / 2$ of the VAT Law). In such cases, the input VAT amount that is not able to be offset against the output VAT amount may be offsetting from other taxes, social security premium, debts relevant to municipalities and other public administration or refunded on the basis of the principles to be determined by the Ministry of Finance (See Oktar, 2018: 216, 217).

\subsection{Taxpayer and Tax Responsible of VAT}

The parties liable for the payment of the VAT are the persons making delivery of goods and providing services. However, persons who buy services or goods can be held responsible from the payment of VAT in certain transactions (Kaneti, 1989: 389; Mutluer, 2007: 284; Şenyüz, Yüce \& Gerçek, 2018: 258).

Article 9 of the VAT Law, arranges the topic of tax responsible, which is the key subject within the scope of our paper. According to first paragraph of this article, if the taxpayer hasn't got any residence, place of business, a legal headquarter or business center in Turkey and, in other cases considered necessary, by the Ministry of Finance, the parties of the taxable transactions may hold responsible for the payment of VAT in order to secure the tax claim. There is also new paragraph was added wording as (Aydın, 2009: 126) "VAT amount regarding the services performed electronically to real persons who are not VAT taxpayer by the party which has not any residence, place of business, a legal headquarter or business center in Turkey is declared and paid by the service providers rendering such service. Ministry of Finance is authorized to determine procedures and principles of the application and scope of the said services performed electronically", in November 28, 2017.

It is understood from the above provisions that the article 9 of VAT Law regulates a tax responsibility for the taxable events made by non-resident taxpayers (Oktar, 2018: 191). In the event that a non-resident person or legal entity derives income from a Turkish resident via delivery of goods or performance of a service, VAT is calculated, declared by VAT return No. 2 and paid by the Turkish resident as tax responsible. So, as a general rule, non-residents are not responsible for the payment of VAT. Finally, the new paragraph stated above regulates the liability of foreign electronic service providers. At this point, what does it mean to be "electronic service provider" and what measures would be taken is the questions that we would like to 
analyze in following chapters. Because, this change does not stand for creating a new type of liability. Taxpayers of the sales transaction made from abroad are always foreign side. What has changed according to that regulation is basically about tax responsibility. Pursuant to the new system explained below in detail concerning taxation of B2C e-commerce, customer is no more involved in this transaction as tax responsible.

\subsection{Imposition, Accrual and Collection of VAT}

Tax basis of VAT is purchase price of goods or services, which means VAT is calculated over the invoiced sale amount (Mutluer, 2007: 294). Pursuant to the article 20/2 of the VAT Law, tax base covers and totals of money borrowed all type of properties, benefit and service or other things with monetary value. Tax base includes transportation, loading and unloading expenses made by the sellers to the place determined from the recipient, packing costs, insurance amounts, commissions and such expenses, taxes, duties, levies and charges and contributions to the funds, delay interest, price difference, incomes as interest and premium, any benefit and service or value under different names, stated under the article 24 .

In accordance with the article 39/1 and the General Communique on VAT Application (hereinafter "General Communique"), the Ministry of Finance set out every month as taxation period for the taxpayer and tax responsible. In this regard, VAT Return No. 1 should be submitted by the VAT taxpayer to the relevant tax office until the 20th day of the following month of relevant taxable event and accrued tax shall be paid until the end of the 26th day of the same month. However, pursuant to the said General Communique, VAT arisen from import transactions shall be declared and paid together with custom duties.

The legislator determined the general VAT rate as $10 \%$ (article $28 / 1$ of VAT Law). On the other hand, the above said article had been given the Council of Ministers the authorization to reduce this rate down to $1 \%$ or increase it up four times and specify tax rates for various goods and services and retail phase for some of the goods, by the time the article 90 of the Decree Law No. 700 came into force on July 7, 2018 and assigned the mentioned authorization within the same scope to the President of the Republic. In this context; all deliveries of goods and services that take place in Turkey are subject to VAT at rates varying from $1 \%$ to $18 \%$ according to the Decree of the Council of Ministers, No. 2007/13033 (hereinafter "Decree").

Although the VAT rate less than $18 \%$ is usually exceptional, there are some goods and services, the VAT rate of some goods and services were reduced to $8 \%$ for List II or $1 \%$ for List I annexed to the Decree, such as yarns and filaments used in the production of yarns, all types of fabrics, internal and external clothes. The VAT that a taxpayer pays for goods and services purchased (input VAT) can be offset against (deducted from) the VAT calculated on deliveries of goods and services made (output VAT). When the amount of output VAT is greater than the input VAT, the difference shall be paid to the tax office by the taxpayer (Aydın, 2009: 114-115). In the event that 
the reverse is true the balance is carried forward to be offset against future output VAT. In other words, the taxpayer is required to submit VAT returns to the tax office on monthly basis. The VAT difference to be paid to the tax office is calculated by way of deduction of the output VAT amount from the input VAT amount. In the event that the reverse is correct, the input VAT amount exceeds the output VAT, the balance is carried forward to be offset against future output VAT amount and transferred to next taxation period (Kaneti, 1989: 391). Thus, it is not refunded. This regulation is so-called "reverse charge mechanism" and does not create any tax burden for both Turkish and non-resident individual, except for its cash flow effect for the former (Biçer \& Uslu, 2018). This system relies on taxpayers who are obliged to register themselves and submit a monthly tax return. This system is used mostly transactions between business to business (B2B) (Özdemir, 2014: 58).

Regarding the above issue, as per the chapter titled "Deduction of VAT paid by Tax Responsible" of the Communique Serial No. 49 VAT, the tax responsible could deduct the VAT amount within the scope of declared tax return No. 2 from the tax return No. 1 in the same month. However, the taxpayer's right to deduct the real accrued VAT is applicable providing that the invoices and similar documents have to contain VAT amount, issued and recorded in legal books. In addition to that, the application of deduction shall not be exceeded the calendar year of registration date pursuant to the article 29/3 of VAT Law (Oktar, 2018: 215; Aydın, 2009: 115).

\section{New System in Taxation of B2C (Business to Customers) E-Commerce and Its Problems}

When the digital transactions are not properly taxed, e-commerce can damage the competition in the market and cause heavy tax burden on classic consumer (Ünsal \& Ubay, 2017: 24). At the one side we see, EU trying to solve this problem and abolish geo-blocking regulations in order to get neutral cross-border digital transactions among its countries. They want to be sure that it is equally profitable to do online shopping between EU countries. (Hutchinson, 2018: 297-298). This problem is solved in EU within B2B context with "Mini One Stop Shop". (Çetin Gerger and Gerçek, 2016, 70). Where firms are registered in one country of EU and this country is responsible of both collection and distribution of collected tax among EU countries. However EU is also struggling to deal with B2C (Business to Consumer) transactions. Turkish Ministry of Finance has published a Communique No. 17 on VAT (hereinafter "Communique 17 ") in an attempt to solve the problem about inefficiency of old system, where final consumer did not committed to perform his duties as tax responsible. This regulation actually based upon the article 41 of the Law numbered 7061 ("Amendment of Certain Taxes and Laws and other Acts"), dated November 28, 2017 and has amended the article 9 of the VAT Law (Dikmen, 2018: 99). The Communique is regulating taxation of the sales of electronic goods to individual customers with no VAT-registration. The target groups of this regulation are parties that have no residence, workplace, 
registered head office and business center in Turkey and whose services provided electronically (Budak, 2018: 73). Although target group was clarified by Communique, new system founds its real roots in code itself. That is a good point to highlight in respect of principle of legality for taxes. This regulation is actually a successor in respect of digital taxation. There was also a change in article 11 of VAT Law relating withholding mechanism in income tax and corporate tax. (Öksüz \& Türgay, 2018: 151152.)

Before that legislation, there was a different mechanism going on in the area of VAT. In past, the above-mentioned general VAT application namely "reverse charge mechanism" was in force regarding these e-commerce transactions. Foreign supplier of electronic goods was not coerced to register for VAT. Because, their resident customers were responsible on behalf of them. The customers located in Turkey were obliged to declare the realized VAT with the "VAT Return No: 2" and then can benefit from tax deduction when they would give their own personal "VAT Return No: 1". Therefore, customers were tax responsible in this system, upon the transactions they have made. However, this application was not ensured to collect VAT derived from B2C e-commerce due to the fact that consumers were not followed in the matter of their responsibilities on VAT Return No: 2 .

The efficiency of old system, will actually be assessed separately herein below, was highly doubted (Ceran \& Çiçek, 2014: 303). In short, applying reverse charge mechanism in B2C sales was a big fail for Turkey (Yüce \& Akbulut, 2018: 117). Demanding individual customers to remit tax on remote services was too much of a burden. As Hellerstein puts it this was a "tax on honesty" and did not really work (Hellerstein, 2016: 621). Therefore, new system, with aforesaid changes was introduced. With this new system, electronic service providers have to register and submit tax return for VAT. This declaration will happen via 'VAT Return No: 3'. In case of violation of these obligations, according to Communique 17, punitive provisions of Turkish Tax Procedural Code No. 213 will be revoked. Before we explain in detail, one can say about new system is more effective from old one. However, it misses again certain points such as regular feedback of banks related to transactions executed by electronic service providers as we also explained in following chapters in detail.

\subsection{Taxable Event on the B2C E-Commerce}

Turkish VAT Law attributes the taxable event in any delivery and service to be based in Turkey (Art. 6). In this regard, selling online electronic goods deemed as a service. OECD and other countries accepted that as such. (Pozvek, 2017: 39). Especially with cloud computing, the electronic service approach is getting stronger and become more extensive (Hojnik, 2018: 74). The virtual stores get a commission over the amounts derived from application sales (Kükrer, 2016: 584). In this regard, article 11 of EU Regulation (1777/2005) gives us guide to define electronically supplied service as 
"Electronically supplied services shall include services which are delivered over the internet or an electronic network and the nature of the service in question is heavily dependent on information technology for its supply". Since the benefit of e-commerce takes place in Turkey, it is also deemed that service was given in Turkey according to Turkish law and subject to VAT. Therefore, whenever electronic sales transaction of goods to a customer in Turkey is completed, taxable event occurs. Draft Communique 17 was enumerated some of the transaction types however, this was not a numerus clausus enumeration. "Electronic Services are defined under 3 main categories: Radio and television broadcasting services, Telecommunication services, Other services provided in electronic environment. Monitoring or listening to radio and television programs at a user-selected time, depending on a program catalog organized by the media service provider. Voice, written and visual telephone services over the Internet. Accessing or downloading music, voices outside of music, movies. Accessing or downloading electronic books and other electronic publications. Accessing games or downloading games, in-game purchases and services for remote play of games. All kinds of software supply (including access and download) and updating" (Whole list was enumerated on www.digitalservice.gib.gov.tr; KPMG, 2017. For more general scope of e-commerce Yüce \& Akbulut, 2018: 110).

Therefore, Communique 17 uses a broader scope with the term "electronically provided service" (Ekinci, 2018). Finally, we would like to point out in the context of Communique, when transaction made in foreign currency, tax will be evaluated on Turkish lira upon the currency published by Turkish Central Bank at the day of taxable event (Karakoç, 2018: 54).

\section{2. "Electronic Service Provider" as Taxpayer}

As it stated above, taxpayer of this kind of transaction is non-resident seller acting without creating a business office or permanent establishment in Turkey, named as "electronic service provider". So what does it mean to be an electronic service provider? This terminology was introduced Turkish legal system just recently and yet with the Communique 17 .

As we first look to text of the Turkish VAT Law Art. 9, we see the phrase "the services performed on electronic medium". What are those services? Are there any specific criteria (threshold etc.) to be deemed an electronic service provider other than that vendor just having no nexus in Turkey and to deliver digital services to real persons? These questions remain unanswered in the mere text of the law. What law does, is to link (direct) us to secondary legislation. Article 9 follows, "Ministry of Finance is entitled to set procedure and principles related to implementation and also scope of the services performed on electronic mediums." With these reference we find Communique 17 published by Ministry of Finance. 
Communique 17 states in 2.1.2.1.2.1, "Whoever has the right of claiming compensation from customer, setting the general clauses related to service or obliged to perform the service would be deemed as electronic service provider." Therefore, that is the definition of electronic service provider. This means it is possible to be a taxpayer, without performing a service. For example, Play Store would be classified as taxpayer as it holds right to claim for compensation, although it did not perform any service. However, the view of the OECD is that a website or website hosting arrangement through an internet does not in itself constitute a permanent establishment (Bardopoulos, 2015: 203).

In this case, another question arises, if the obligation to perform and to claim compensation lies with two different identities, which one should be identified as the electronic service provider? According to us, it can be both. Because, in the case of Play Store it also possible to claim that Google is both obliged to perform (in the name of developer) and entitled to claim compensation. Therefore, there is room for legal ambiguity on this point.

It is said in the Communique 17 that "where electronic service provider did not explicitly state or it is not written on the contract between parties or, it is not reflected on the invoices or other related documents, value added tax related to services performed on electronic medium shall be declared and paid by who intermediates the electronic service supply". So, in the event that electronic service provider cannot be determined within the scope of electronic agreements, invoices or etc., the intermediaries are characterized as tax obligatory. However, this provision of the Communique is worth to highlight. It is not clear what is to be an intermediary. Is the Communique referring to banks, other payment intermediaries, proxy servers or just persons? There may be also another option that, is it just referencing platforms that enables people to sell their digital product via popular electronic store (i.e. Play Store, Apple Store). As we stated above, when we are unable to find real taxpayer, we can detect it by the measure of right to claim compensation. In most of the cases, platforms (digital stores) as such would be responsible as electronic service providers.

\subsection{Taxpayer Threshold for Foreign Vendors to Register as Electronic Service Provider}

When non-resident vendor performs a service in an electronic medium to nonVAT responsible consumer, taxable event occurs regardless of this service having the value whether 1 or 1000 Turkish Lira. As we see, there is no threshold for non-resident vendors to enjoy refraining to register their profit (Konca \& Durgun, 2018). As the OECD puts it, it is the duty of the country of taxation to simplify and make it easy the process of compliance for non-resident vendors (OECD, 2015). This regulation of Turkey can influence the compliance rates negatively. 
USA, EU and most of the other countries have thresholds for foreign vendors to register (Silva, 2014: 161). In fact, some studies show that compliance level is low when there is no threshold (Satterthwaite, 2018: 195-196). Since Turkey applies no threshold yet for its local companies, it could be a great chance to test it first on foreign vendors.

In the case of threshold, how do countries check if the vendors exceed that limit is another question. However, for example in Norway, government wants nonresident vendors to register after exceeding one threshold and adds that if government detects that vendor already exceeded that threshold then vendor should pay the occurred tax (The Norwegian Tax Administration, 2017). In our view, Turkey should put a threshold in order to protect both tax neutrality and potential revenue problem. In Turkey (Communique 17, 2.1.2.1.2.2.) and as well as in EU (European Council, 2011: Art. 63c), non-resident vendors are not obliged to keep books. They are obliged to keep the invoices and other related documents for 10 years (European Council, 2006: Art. 369/2 and 369k.) in EU (EU Commission, 2016: 17) and 5 years in Turkey. These documents should be kept ready for presentation when the controllers have asked to do so. In Turkey, if they fail in preservation and presentation of aforesaid documents there will be consequences with regard to tax evasion and tax assessment together with tax penalty.

However, when there are no books to analyze in detail, above all to assess basis, and to do cross check, it is very hard for tax administration to investigate the accuracy of tax returns. Other obstacle in front of the local tax administration is the audit. When there is no physical existence and no books whatsoever, it is impossible to conduct a classic audit. Other versions such as electronic audit could be the solution. Or in more classical way, basis valuation commissions will calculate the basis, administration will accrue the tax and if the vendors think differently than they should prove it otherwise on their own before the court. Since the taxpayer failed his duty to inform the tax authority prior to assessment, now burden of proof relating the inaccuracy of assessment would be on his shoulders.

Last solution brings so much compliance burden on the shoulders of nonresident small and medium enterprises. Since these small and medium enterprises will not possibly have a chance for legal counsel in Turkey it will damage their business (Karakoç, 2018: 55).

\subsection{Place of Taxation and Other Problems}

Problem of place of taxation is the problem of which law should be applied to supposed taxable event. Either sellers or customer's country law will be governing. Sellers place redeemed as place of taxation on cross border sales of digital goods in EU before 2015. However, it was changed because of BEPS initiative (EU Commission, 2016: 17). 
When place of taxation was accepted as sellers' location, sellers who exports digital goods to foreign countries did enjoy great exemptions. Since countries wanted to boom their export industry, limit for exemptions was high (Pozvek, 2017: 38). However, when some countries of European Union started to set their limits very high, then small and medium enterprises started to settle themselves in those countries and following caused tax erosion for other countries (Öksüz \& Türgay, 2018: 146; Budak, 2017: 298; EU Commission, 2016: 17).

As a result of above said discussions, EU has changed its place of taxation rule in 2015 to customers' location (Hojnik, 2018: 78). Since OECD's Base Erosion and Profit Shifting Action number 7 requires to define digital nexus (Mastar Özcan, 2016: 79), it is suggested by OECD to establish new type of nexus based on "significant economic presence" (Budak, 2017: 310).

How was the situation in Turkey? Namely, place of taxation on cross border import of B2C digital goods has been always customers' location in Turkey. As stated above, Turkish VAT Law attribute the taxable event in any delivery and service to be based in Turkey (Turkish VAT Law Art. 6). At this point, selling online electronic goods deemed as a service. OECD and other countries accepted that as such. As a result, since the benefit takes place in Turkey it is also deemed that service was given in Turkey according to Turkish VAT Law Art. 6 (Yaltı, 2003: 233; Çetin Gerger, 2011: 65). We can conclude that, Turkey's approach to place of taxation in this matter was true, even before the new legislation of EU after 2015.

\subsection{General Measures to Enforce New System}

Communique 17 states that in the case of non-compliance of new system as mentioned above is occurred, punitive measures of Turkish Tax Procedural Code will be revoked. However, before that, an ex officio assessment derived from the article 30 of the Tax Procedure Law No. 213 will be made. In Turkish tax law, there are four ways to assess tax basis. These are; based on (self-assessment) tax return, ex officio, additional and administrative assessments.

According to the imposition over the tax return, tax administrations are obliged to assess and accrue the tax by taking into consideration the tax payers' written declarations including the tax basis. Apart from first method, tax administrations mostly assess the basis in person (Öncel, Kumrulu \& Çağan, 2015: 95). In such circumstances, when the tax basis cannot be detected in part or whole from books, records, documents or other statutory measures or situations and also in the event of violations of the obligation to submit a tax return, tax administrations are obliged to assess the tax through ex officio method. In such circumstances; lacks of books, invoice or other documents are not hindering tax administration to make an assessment.

Obviously, it is a technical matter to assess tax basis. Thus, basis valuation commissions may be deployed. These commissions are consisted of both agents of tax 
administration and representatives of taxpayers (Tax Procedure Law, Art. 72). These commissions have auditing authorization and so the Turkish Court of Cassation Regional Administrative Court and/or Council of State- expects them to fulfill this obligation (Aslan \& Karakoç, 2016: 261). They should, if they found any, check the books or other documents. However, if those documents lack, they are also entitled to base their assessment upon criteria such as; sector of taxpayers, general profit, business volume, capital sum, how many workers are employed, state of stocks etc. (Karakoç, 2011: 717).

Interestingly, it is not possible for taxpayers to claim nullity by action against the reports of basis valuation commissions whereas for tax administration means for action is open. Upon the result of the attitudes of tax administration, taxpayers may be faced with two different scenarios. In first scenario, tax administration does not take an action against the report and assess the basis in compliance with report, and then sent notice. At that point, if the taxpayer takes an action for this notice then he can prove the contrary of report by expert and other complementary evidence. In second scenario, tax administration takes an action against the report and court does not find that commission decision justified. In this situation; some authors say that if authenticity of report is approved by court, it will be impossible to apply administrative remedies such as negotiation -in German Law "tatsächliche Verständigung"- (Karakoç, 2011: 707). However; in any case, if the taxpayer does not involve with the judicial procedure at the end, it should not be forgotten that he will be faced off with a precautionary attachment issued by tax office. If that doesn't work, some of the authors discuss the possibility of blockage of access to internet site which noncompliant firm operates (Karakoç, 2018: 54).

\subsection{Punitive Measures Against the Violation of New System}

According to this matter, Turkish Tax Procedural Code regulates 3 different way of punitive measures. First one is loss of tax fine, second one is special irregularity fine and the last one is general irregularity fine. Starting with first, Tax Procedure Law Art. 344 says "when loss of tax arises in accordance with the conditions stated in Art. 341, taxpayer or tax responsible will be fined with the amount of tax have been lost". In this context, Art. 341 of Tax Procedure Law states that "tax loss means, late or less accrual of tax, due to default of obligations in respect of time, or less fulfillment of these obligations by taxpayer or tax responsible". Article 5 of the Law on Collection Procedure of Assets, No. 6183, provides a late fee for the payment made after the due date, in rate published in Presidential Decree numbered 62 as "2\%" per month.

When it comes to special irregularity fines, we first encounter with the obligation of e-tax return. Communique stated that "electronic service provider" should electronically declare their "VAT Return No: 3". They are not obliged to submit blank return if they don't cause taxable event to occur (Dikmen, 2018: 101). However, 
in the case of negligence of general obligation (when taxable event occurs), a fine will be arisen (Art. reiterated 355/4 of Tax Procedure Law). This fine is irrelevant of tax loss fine. Amount of penalty is gradual and changes every year with the decree of President. This year's amounts are highest being 1.400 Turkish Liras and lowest being 350 Turkish Liras. There is also a discount mechanism on the execution of this fine. When vendor submits his late e-tax return by 30 days later he gets $1 / 10$ th of the aforesaid punishment, and after 60 days, rate increases to 2/10th. Finally, after 60 days of negligence, punishment is full whether e-tax return has submitted or not.

Additionally, according to Communique 17, it is possible for electronic service providers to enjoy VAT refund under special conditions. In order to get VAT refund, "electronic service providers" should have bought something related to their provided service from resident VAT responsible sellers in Turkey. Invoices of these transactions should be kept and exhibited on demand. If these keeping obligations are omitted, article 352 of Tax Procedure Law applies. This irregularity fine is a fixed fine and changes every year, which is applicable 80 Turkish Liras for 2018.

\section{Conclusion and Evaluations}

Within this paper, we have tried to analyze recent Turkish approach in taxation of B2C e-commerce. We have stated that globalization and the internet made ecommerce as complex as never before. Consequently, firms can operate on a crossborder level without needing any of residence or place of business. Within this concept, therefore, it is almost impossible to tax these entities in respect of corporate tax. On the other side, developing countries, like Turkey, do not want to discourage the investors but they also want to minimize the revenue loss. However, in short our first impressions are quite positive about new regulation.

To solve this problem, VAT comes our help. As we stated, there are different methods to collect VAT. Turkish government did put away one of the inefficient methods for B2C transactions, namely "reverse charge mechanism" and introduced somehow more effective register system.

Obviously, government has to be informed from transactions in order to check accuracy of tax returns. Within the context of B2C commerce, Turkish banks were first obliged by law to regularly report cross-border transactions which payment made through them in Draft Communique 17. However, this article was removed in Communique 17's last version. It is most likely that Turkish government prepares legal and technological infrastructure to lay out this mechanism. Once this mechanism laid out, there will be also room for Turkish banks in execution/confiscation provisions. As of now, all banks taking part within electronic payment system are obliged to provide information about B2C e-commerce transactions if requested by the Ministry of Finance in the context of article 148, 149 and 151 of Turkish Tax Procedural Law No. 213. As a result, tax assessments can be made according to the informations related 
to electronic commercial transactions gathered from banks. However; there is no regular feedback of banks related to transactions executed by electronic service providers and determination of which tansactions or vendors are within the scope of information garhering sysytem. The main reason of such uncertainties is the status of undetermined threshold for relevant transactions.

On the other hand, it should be taken into account that absence of assets of foreign electronic service provider is a big problem for enforcement. Within the context of this problem, which effective forcible method will be followed in order to collect such tax amounts becomes another uncertain subject. Therefore, this problem of collection method should be considered on a preferential basis and clarified. The first method coming into mind is that to collect the overdue tax debts via "electronic attachment system" that allows an electronic attachment procedure applicable on monetary claims arisen from payment orders made by consumers. However, we think that this kind of "e-attachment" applications may break the international banking system on credit card provision and create private law problems between banks and claimants ("electronic service providers").

To sum up, firms started to submit their tax returns by April 2018. They continue as now to do so. From this point of view, new system is actually working quite well. Nevertheless, it is also ambiguous to detect what would be in case incompliance. There is yet no judicial or administrative decree on this point. However, we guess, there is enough instrument in Turkish Tax Procedural Code to ensure the payment of the tax. Both administrative assessment and tax fines will help to accomplish that task. When it comes to the enforcement of these measures, banks may help to achieve that objective. We expect the regulations in future which oblige them to inform adminstration related electronic transactions. Moreover, Turkish tax law allows administration to apply electronic attachment to bank accounts. When the necessary legal infrastructure laid out, banks could take active role in such attachment. In this case, vendor's account primarily and consumer's as secondarily may encounter with this measure of attachment.

\section{References}

Aslan, O. \& Karakoç, H. (2016). Vergi Hukukunda Takdir Komisyonu Kararları Hukuki Niteliği, Adalet Yayınevi, Ankara.

Aydın, E. (2009). Katma Değer Vergisinde Sorumluluk, On İki Levha Yayınevi, İstanbul.

Bardopoulos, A.M. (2015). "ECommerce and the Effects of Technology on Taxation Could VAT be the eTax Solution?", Law, Governance and Technology Series, 22, 
Springer,

https://link.springer.com/book/10.1007/978-3-319-15449-7

(08.02.2019).

Biçer R. \& Uslu, Y. (2018). "Turkey: New VAT liability for non-resident electronic service providers", http://www.internationaltaxreview.com, (10.02.2019).

Budak, T. (2018). T. Dijital Ekonominin Vergilendirilmesi, On İki Levha Yayınevi, İstanbul.

Budak, T. (2017). "The Transformation of International Tax Regime: Digital Economy", Inonu University Law Faculty Journal -InUHFD, 8(2), 297-330.

Ceran, Y. \& Çiçek, R. (2014). “Elektronik Ticaretin Vergilendirilmesine Iliş̧kin Türk Vergi Sisteminde Katma Değer Vergisi Açısından Bir Değerlendirme”, Yönetim ve Ekonomi: Celal Bayar Üniversitesi Iktisadi ve Idari Bilimler Fakültesi Dergisi, 14(1), 291-304.

Çetin Gerger, G. (2011). “Elektronik Ticarette Tüketim Vergisi Olarak KDV'nin Etkinliği”, Ekonomi Bilimleri Dergisi, 1(3), 59-67.

Çetin Gerger, G. \& Gerçek, A. (2016). "Elektronik Ticaretin Vergilendirilmesi Açısından Katma Değer Vergisinin Uygulama Sorunlarının Değerlendirilmesi” International Journal of Public Finance, 1(1), 61-74.

Dikmen, M.B. (2018). "Türkiye'de Mukim Olmayan Kişiler Tarafından Elektronik Ortamda Sunulan Hizmetler İçin Getirilen 3 No.lu KDV Beyannamesi Uygulamasına iliş̧kin Usul ve Esaslar", Vergi Dünyası, 439, 99-101.

Ekinci, E. (2018). "New VAT Liability for non-resident suppliers of Electronically Supplied Services in Turkey", International VAT Monitor, https://www.ibfd.org/sites/ibfd.org/files/content/marketing/Journal_Previews /IVM/IVM-5_2018.htm, (20.02.2019).

European Commission (2016). Commission Staff Working Document, Impact Assessment Accompanying the document: Proposals for a Council Directive, a Council Implementing Regulation and a Council Regulation on Modernizing VAT for cross-border B2C e-Commerce (1 December 2016, SWD(2016) 379 final), Brussels, https://eur-lex.europa.eu/legal-content/EN/TXT/PDF/?uri=CELEX: 52016SC0379\&from=EN, (20.02.2019).

European Council (2006). Directive 2006/112/EC, https://eur-lex.europa.eu/legalcontent/EN/TXT/PDF/?uri=CELEX:32006L0112\&from=EN, (13.02.2019).

European Council (2011). Implementing Regulation (EU) No: 282/2011, https://eurlex.europa.eu/legal-content/EN/TXT/PDF/?uri=CELEX:32011R0282\&from=EN, (13.02.2019).

Hellerstein, W. (2016). "A Hitchhiker's Guide to the OECD's International VAT/GST Guidelines", Florida Tax Review, 18(10), 589-637. 
Hojnik, J. (2018). "Digital Content as a Market Commodity Sui Generis: EU Lawyers (Finally) Moving from Newton Physics to Quantum Physics", 22nd Economic and Social Development, International Scientific Conference on Economic and Social Development: The Legal Challenges of Modern World, (Eds.) Radic, Z., Roncevic, A. \& Yongqiang L., Split, 73-84.

Hutchinson, C.S. (2018). "Challenges to Competition of Geographic Restrictions to Online Sales of Goods and Digital Content", Law in the Modern World: J. Higher Sch. Econ., 4, 270-299.

Kaneti, S. (1989). Vergi Hukuku, Filiz Kitabevi, İstanbul.

Karakoç, Y. (2011). Genel Vergi Hukuku, Yetkin Yayınevi, Ankara.

Karakoç, ì. (2018). "Katma Değer Vergisinde Yeni Dönem: 3 No'lu KDV Beyannamesi", Vergi Sorunları Dergisi, 41(354), 51-55.

Konca, A. \& Durgun, G. (2018). "Turkish tax authority publishes VAT guidance for nonresidents providing e-services to Turkish resident individuals", https://www.ey.com/gl/en/services/tax/international-tax/alert--turkish-taxauthority-publishes-vat-guidance-for-nonresidents-providing-e-services-toturkish-resident-individuals, (10.02.2019).

Kükrer, C. (2016). “Internet Ortamında Bazı Faaliyetlerin Kavramsal Tanımları ve Türk Vergi Sistemi Karşısındaki Durumlarının Değerlendirmesi”, Yönetim Bilimleri Dergisi, 14(27), 583-604.

KPMG (2017). "2017/5 New VAT Regime for e-Services in Turkey", https://kpmgvergi.com/Yayinlar/MaliBultenler/Pages/MaliBultenDetay.aspx?id en=1848\&type=Mali\%20B\%C3\%BCltenler, (31.03.2019).

Mastar Özcan, P. (2016). “Dijital Ekonominin Vergilendirilmesinde Karşılaşılan Sorunlar: BEPS 1 No'lu Eylem Planı Kapsamında Bir Değerlendirme”, Electronic Journal of Vocational Colleges, 2(2), 73-82.

Mutluer, M.K. (2007). Vergi Özel Hukuku, İstanbul Bilgi Universitesi Yayınları, İstanbul.

OECD (2015). International VAT/GST Guidelines, https://read.oecdilibrary.org/taxation/international-vat-gst-guidelines_9789264271401en\#page1, (22.02.2019).

Oktar, S.A. (2018). Türk Vergi Sistemi, Türkmen Kitabevi, İstanbul.

Öncel, M., Kumrulu, A. \& Çağan, N. (2015). Vergi Hukuku, Turhan Kitabevi, Ankara.

Öksüz, M. \& Türgay, T. (2018). “Türkiye'de Elektronik Ticaretin Vergilendirilmesi Ve Tevkifat Müessesesi", Journal of Administrative Sciences, 16(32), 135-156.

Özdemir, S. (2014). “Elektronik Ticarette KDV Uygulaması”, Vergi Sorunları Dergisi, 310, 54-60. 
Ünsal, H. \& Ubay, B. (2017). "Katma Değer Vergisinde Vergilendirme Yetkisinin Uluslararası E-Ticaret İşlemleri Açısından Değerlendirilmesi", Vergi Raporu Dergisi, 211, 9-26.

Pozvek, M. (2017). "VAT in Digital Electronic Commerce”, Intereulaweast Journal, IV(1), 37-53.

Satterthwaite, E.A. (2018). "On the Threshold: Smallness and the Value-Added Tax", Columbia Journal of Tax Law, 9(177), 139-226.

Silva, A.P. (2014). "VAT registration in Europe: A Review", Publishing Research Quarterly 30, (Ed.) Baensch, R.E., 30(1), 152-165.

Şenyüz, D., Yüce, M. \& Gerçek, A. (2018). Türk Vergi Sistemi, Ekin Basın Yayın Dağıtım, Bursa.

Şişman, G. (2014). Danıştay Kararları ve Özelgeler Işığında Katma Değer Vergisinde Vergiyi Doğuran Olay, Seçkin Yayınevi, Ankara.

The Norwegian Tax Administration (2017). "Value Added Tax on Electronic ServicesVOES" https://www.skatteetaten.no/en/business-and-organisation/foreign/ foreign-companies/vat/voes/, (10.02.2019).

Yaltı, B. (2003), Elektronik Ticarette Vergilendirme, Der Yayınları, İstanbul.

Yüce, M. \& Akbulut, N. (2018). "BEPS Eylemi Kapsamında Dijital Ekonominin Vergilendirmesine İlişkin Alınan Önlemler", Akademik Bakış Dergisi, 68, 105123. 